\title{
Modeling Of Solar Photovoltaic Assisted Vapor Absorption Refrigeration System for Running an Ice Factory
}

\author{
Kamaljyoti Talukdar ${ }^{1}$ \\ ${ }^{I}$ (Assistant Professor, Mechanical Engg. Dept., Bineswar Brahma Engineering College, Kokrajhar,Assam,India
}

\begin{abstract}
In this study a detailed analysis for running an ice factory in city New Delhi located in India has been analyzed. The ice factory is operated throughout the day and throughout the year. The solar photovoltaic $(P V)$ modules is used for powering of vapor absorption refrigeration system(VARS). The ice production of the ice factory is done by the evaporator of VARS. The cooling load of evaporator is 50 TOR(tones of refrigeration) and heat exchanger effectiveness is 0.8. The water is converted to ice to $-10^{\circ} \mathrm{C}$ from ambient temperature. It is found that 5943 modules in parallel (each having two modules in series) of Central Electronics Limited make PM 150 can meet the electrical energy demand of the VARS throughout the year. The power back up is provided using battery bank of rated capacity of $59430 \mathrm{Ah}$.
\end{abstract}

Keywords: Ice factory, photovoltaic modules, tones of refrigeration, vapor absorption refrigeration system

\section{Introduction}

Refrigeration is the most demanding technology in today's world. In vapor compression refrigeration system (VCRS), electricity (high grade energy) is used for refrigerating. This electricity is produced from conventional sources like coal, petroleum by power plants. These conventional fuels will finish one day. So research is going on to use non conventional sources for refrigeration. It may be solar, geothermal etc..The best way of using non conventional sources for refrigeration is vapor absorption refrigeration system (VARS).Many authors have analyzed refrigeration principle in different ways. Chedop et al.[1] presented an assessment of a solar electric-vapor compression refrigeration (SE-VCR) system in a dry tropical area of city of Maroua $\left(14.33^{\circ} \mathrm{E}, 10.58^{\circ} \mathrm{N}\right)$, located in the Sudano-Sahelian climatic region of Cameroon. Zhai et al.[2] besides reviewing of the existing theoretical and experimental investigations of solar single effect absorption cooling systems, some new design options with regard to solar collectors, auxiliary energy systems and cooling modes were introduced. Chidambaram et al.[3] reviewed reviews research articles in the field of solar cooling techniques, solar collectors, storage methods and their integration, along with performance improvement studies reported using thermal stratification and cascaded thermal storage systems. Hassan and Mohamad[4] presented a comprehensive literature review on absorption based refrigeration and air conditioning systems that were powered by solar energy. Hasnain[5] described the inherent pros and cons of the two common (i.e. chilled water and ice storage) commercially available thermal energy storage (TES) technologies for offe -peak air conditioning applications. Kattakayam and Srinivasan[6] presented the cool-down, warm-up and steady state performance of a $100 \mathrm{~W}$ AC operated domestic refrigerator powered by a field of photovoltaic panels, a battery bank and an inverter. Blas et al.[7] centred on the analysis of a direct current permanent magnet motor integrated in a refrigeration facility for milk cooling. Yi and Dong[8] established ice storage air-conditioning system, by analyzing the mechanism of ice tank, ice melting system outside the tank model. Gupta et al.[9] a parameter study was carried out to find out the best combination of the PV panel wattage, battery capacity and insulation level to operate the refrigerator stand-alone on solar power. Modi et al.[10] described the fabrication, experimentation and simulation stages of converting a 165 litres domestic electric refrigerator to a solar powered one. Cherif and Dhouib[11]presented performances, the simulation responses and the dynamic behaviour of a photovoltaic (PV) refrigeration plant using latent storage. Ganguly et. al[12] developed a model of a solar powered Lithium Bromide - Water $\left(\mathrm{LiBr}-\mathrm{H}_{2} \mathrm{O}\right)$ absorption system for a cooling load of 0.5 ton rating (TR).

Ice production is very important technology.Saito[13] reviewed recent literatures in the field of cold thermal energy storage(CTES). Zhang and Gu[14] constructed a nonlinear programming based on the improved model of facilities to achieve the optimization of the ice-storage air conditioning system.

In the present study, solar photovoltaic modules in conjunction with water- $\mathrm{LiBr}$ vapor absorption refrigeration system are used for producing ice in an ice factory throughout the year for climatic condition of New Delhi city located in India. 


\section{System Layout}

Fig.1 shows the schematic view of configuration when current produced by solar PV(photovoltaic) is more than current required by generator of VARS(vapor absorption refrigeration system) for ice production. The current produced by PV modules is $\mathrm{I}_{\mathrm{PV}}$. It goes through charge controller. In charge controller the excess current after meeting the VARS generator current $\mathrm{I}_{\mathrm{G}}$ i.e. $\mathrm{I}_{\mathrm{PV}} \mathrm{I}_{\mathrm{G}}$ goes to rechargeable battery. The battery stores the energy in electrical form. The VARS generator current goes through inverter and finally $\mathrm{I}_{\mathrm{G}}$ reaches VARS generator.

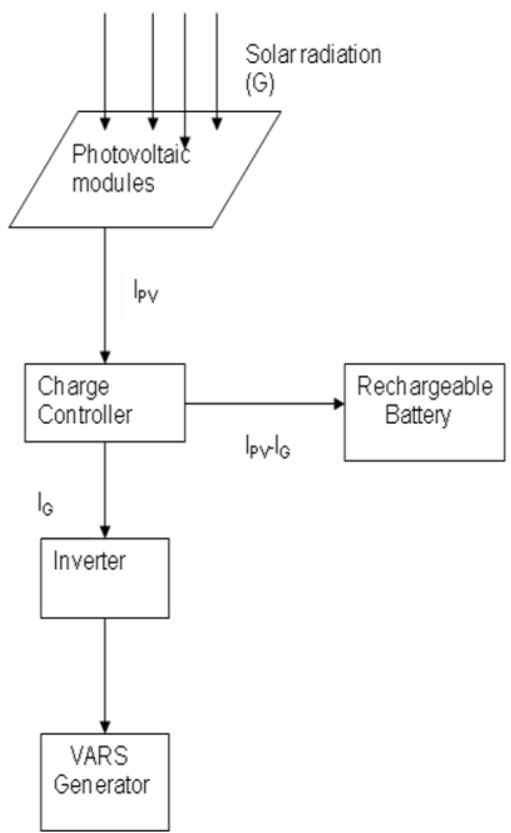

Fig.1 Schematic view of configuration when current produced by solar PV is more than current required by generator of VARS for ice production

Fig.2 shows the schematic view of configuration when current produced by solar PV is less or negligible than current required by generator of VARS for ice production. The current required by the generator $I_{G}-I_{P V}$ is supplied by the rechargeable battery after passing through the charge controller.

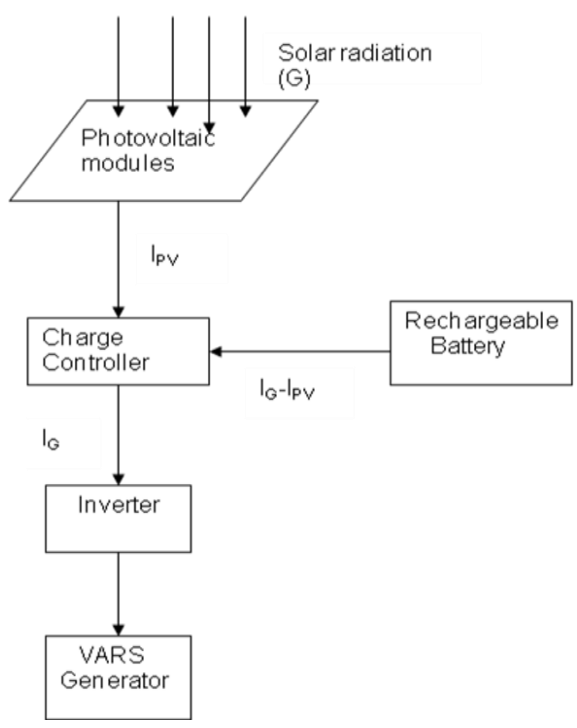

Fig.2 Schematic view of configuration when current produced by solar PV is less or negligible than current required by generator of VARS for ice production 


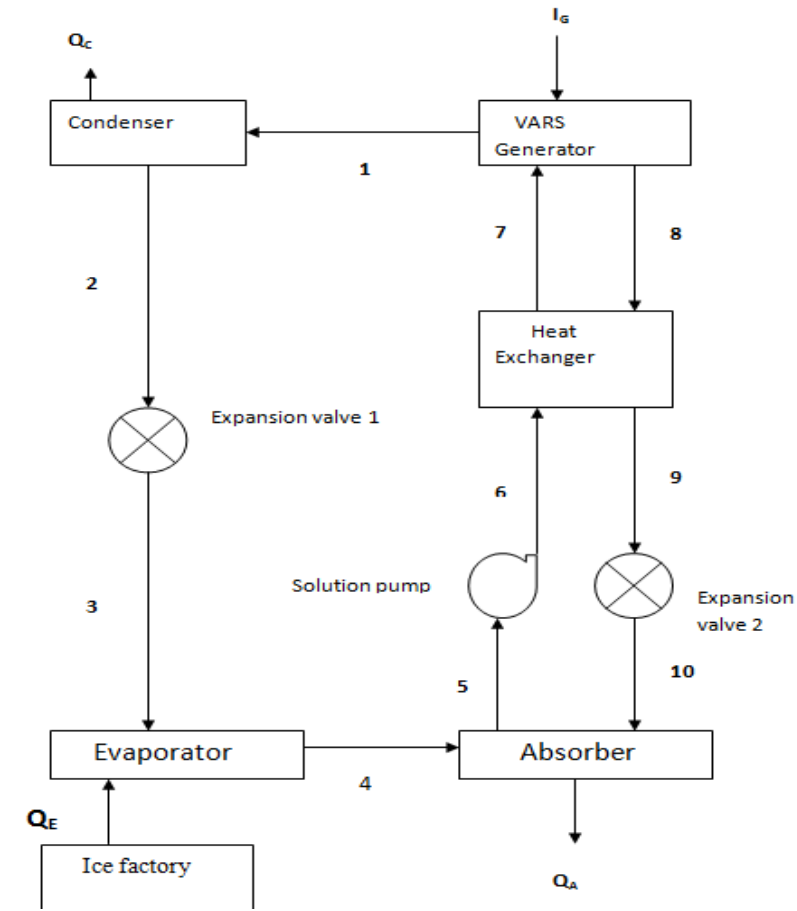

Fig.3 Schematic view of water-LiBr vapour absorption refrigeration system

Table 1 shows the assumed parameters for absorption refrigeration system

Table 1. Operating parameters of various components in absorption refrigeration system.

\begin{tabular}{|c|c|}
\hline Parameters & Values \\
\hline Evaporator temperature & $15^{\circ} \mathrm{C}$ \\
\hline Absorber temperature & $35^{\circ} \mathrm{C}$ \\
\hline Heat exchanger effectiveness & 0.8 \\
\hline Generator temperature & $80^{\circ} \mathrm{C}$ \\
\hline Condenser temperature & $35^{\circ} \mathrm{C}$ \\
\hline
\end{tabular}

\subsection{Modeling of power system}

\section{Model Development}

The electrical energy is generated by harnessing solar energy using photovoltaic modules. In the present work Central Electronics Limited Make PM-150[15]solar photovoltaic module has been used. The single cell terminal current is given by[16]:

$$
i_{P V}=i_{L}-i_{D}
$$

Where $i_{L}$ is the light current generated by a solar cell as a function of solar radiation (G) and $i_{D}$ is the diode current.

The light current generated from a photovoltaic module at any given intensity of solar radiation and temperature is given by[16]:

$i_{L}=\left(\frac{G}{G_{\text {ref }}}\right)\left(i_{\text {scref }}+\mu_{\text {isc }}\left(T_{\bmod \text { ule }}-T_{\bmod \text { uleref }}\right)\right)$

Where, $G, G_{r e f}$ is the solar radiation at actual[17]and reference condition(1000 $\left.\mathrm{W} / \mathrm{m}^{2}\right)[15]$ respectively, $i_{\text {scref }}$-short circuit current at reference condition(A)[15], $\mu_{i s c}$-manufacturer supplied temperature coefficient of short circuit current(A/K)[15], $T_{\bmod u l e}$ and $T_{\bmod u l e r e f}$ module temperature at actual and at reference condition $(\mathrm{K})[15]$. 
The module temperature is a function of ambient temperature $\left(T_{\text {ambient }}\right)$, wind $\operatorname{speed}\left(v_{f}\right)$ and solar radiation $(\mathrm{G})$ and given by [16]:

$T_{\bmod u l e}(K)=\left(0.943 \times T_{\text {ambient }}+0.028 \times G-1.528 \times v_{f}+4.3\right)+273.15$

Where, $T_{\text {ambient }}$ is in ${ }^{0} \mathrm{C}[17], G$ in $\mathrm{W} / \mathrm{m}^{2}[17], v_{f}$-wind speed in $\mathrm{m} / \mathrm{s}[18]$.

The diode current in equation (1) is a function of reverse saturation current and given by [16]:

$i_{D}=i_{\text {sat }}\left[\exp \left(\frac{q\left(V+i_{P V} R_{s}\right)}{\gamma k T_{\bmod u l e}}\right)-1\right]$

Where $i_{\text {sat }}$ - reverse saturation current(A), $q$-electron charge $\left(1.6 \times 10^{-19} \mathrm{C}\right), V$-terminal voltage $(\mathrm{V}), R_{S}$-series resistance, $\gamma$-shape factor, $k$-Boltzmann constant $\left(1.38 \times 10^{-23} \mathrm{~J} / \mathrm{K}\right)$.

$i_{\text {sat }}=i_{\text {satref }}\left(\frac{T_{\bmod \text { ule }}}{T_{\bmod \text { uleref }}}\right)^{3} \exp \left[\left(\frac{q \varepsilon_{G}}{k A}\right)\left(\frac{1}{T_{\bmod \text { uleref }}}-\frac{1}{T_{\bmod \text { ule }}}\right)\right]$

where A-completion factor, $\varepsilon_{G}$-material bandgap( $1.12 \mathrm{eV}$ for $\left.\mathrm{Si}\right)$,and

$i_{\text {satref }}=i_{\text {scref }} \times \exp \left(\frac{-q V_{\text {ocref }}}{k \gamma T_{\text {moduleref }}}\right)$

Where $V_{\text {ocref }}$-open circuit voltage at reference condition[15].

$i_{\text {sat }}, i_{\text {sarref }}$ is taken from[16].

Shape factor $(\gamma)$ which is a measure of cell imperfection is given by[16]:

$\gamma=A \times N C S \times N_{S}$

Where $A, N C S, N_{S}$ is completion factor, number of cells connected in series in a single module(specified by manufacturer of the module) and number of modules connected in series of the entire photovoltaic array respectively.

$N_{S}=\frac{V_{\text {system }}}{V_{\text {mod ule }}}$

Where $V_{\text {system }}$ is the system voltage of the photovoltaic array(considered $48 \mathrm{~V}$ in present study) and $V_{\text {mod ule }}$ is the voltage obtained from single module. 
The current(i) required for any particular hour for VARS generator is:

$$
i=\frac{Q_{G}}{V_{\text {system }} \times P F \times \eta_{\text {inverter }}}
$$

Where $\mathrm{Q}_{\mathrm{G}}$ is the power requirement of VARS' generator( $\left.\mathrm{kW}\right)$ at any hour,PF-power factor $(0.85), \eta_{\text {inverter }}{ }^{-}$ inverter efficiency $(0.85)$

The design current required from photovoltaic array $\left(i_{s p v}\right)$ is given by:

$$
i_{s p v}=\frac{i_{\text {total }} \times D F}{\text { peaksunshinehours } \times \eta_{\text {chargecontroller }}}
$$

Where $i_{\text {total }}$ is the total current for VARS generator in a day, DF is the de-rating factor of photovoltaic module [19] is $1.25, \eta_{\text {chargecontrolle }}$ is charge controller efficiency [19] is 0.85 ,peak sunshine hours is considered 7 hours per day[20].

Number of PV modules connected in parallel $\left(N_{p}\right)$ is given by:

$$
N_{p}=\frac{i_{s p v}}{i_{m p}}
$$

Where $\mathrm{i}_{\mathrm{mp}}$ is the current available from single module under peak power condition.

Net current from solar PV array is: $i_{\text {array }}=i_{p v} \times N_{p}$

\subsection{Modeling of VAR system}

In the VARS, we consider a simple single effect $\mathrm{H}_{2} \mathrm{O}-\mathrm{LiBr}$ absorption system consisting of a $\mathrm{SHE}$ (solution heat exchanger).Concentration of the strong and weak solution of the refrigerant as functions of operating temperatures is known [21].

$$
\begin{aligned}
& X_{s s}=\frac{49.04+1.125 T_{A}-T_{E}}{134.65+0.47 T_{A}} \\
& X_{w s}=\frac{49.04+1.125 T_{G}-T_{C}}{134.65+0.47 T_{G}}
\end{aligned}
$$

Where, $\mathrm{X}_{\mathrm{Ss}^{-}}$strong solution concentration, $\mathrm{X}_{\mathrm{ws}}$-weak solution concentration, $\mathrm{T}_{\mathrm{A}^{-}}$-absorber temperature, $\mathrm{T}_{\mathrm{E}^{-}}$ evaporator temperature, $\mathrm{T}_{\mathrm{G}}$-generator temperature, $\mathrm{T}_{\mathrm{C}}$-condenser temperature.

Thermodynamic properties such as specific enthalpy, entropy of the refrigerant (water) both in liquid and vapour state at various pressures and temperature are determined from International Associations for the properties of water and steam (IAPWS) formulation 1997 [22]. Similarly the thermodynamic properties of $\mathrm{H}_{2} \mathrm{O}-\mathrm{LiBr}$ solutions at various temperatures and concentration are calculated using the correlations proposed by Patek and Klomfar [23].

The mass flow rate of $\operatorname{strong}\left(m_{s s}\right)$ and weak solution $\left(m_{w s}\right)$ is calculated from the following equations [21].

$$
\begin{aligned}
& \dot{m}_{s s}=\frac{\dot{m}_{\mathrm{H}_{2} \mathrm{O}} X_{w s}}{X_{w s}-X_{s s}} \\
& \dot{m}_{w s}=\frac{\dot{m}_{\mathrm{H}_{2} \mathrm{O}} X_{s s}}{X_{w s}-X_{s s}}
\end{aligned}
$$

The thermal load in the generator, absorber and condenser can be expressed as:

$$
\begin{aligned}
& Q_{G}=\dot{m}_{H_{2} O} h_{1}^{\prime}+\dot{m}_{w s} h_{8}^{\prime}-\dot{m}_{s s} h_{7}^{\prime} \\
& Q_{A}=\dot{m}_{H_{2} O} h_{4}^{\prime}+\dot{m}_{w s} h_{10}^{\prime}-\dot{m}_{s s} h_{5}^{\prime}
\end{aligned}
$$




$$
Q_{C}=\dot{m}_{H_{2} O}\left(h_{1}^{\prime}-h_{2}^{\prime}\right)
$$

Where h'-enthalpy at salient points, $\mathrm{Q}_{\mathrm{G}}$-generator load, $\mathrm{Q}_{\mathrm{A}}$-absorber load, $\mathrm{Q}_{\mathrm{c}}$-condenser load.

\section{Results And Discussions}

A computer code in C language was written to simulate combined photovoltaic system and VAR system. Following are the results and discussion.

\subsection{Analysis for the month of January}

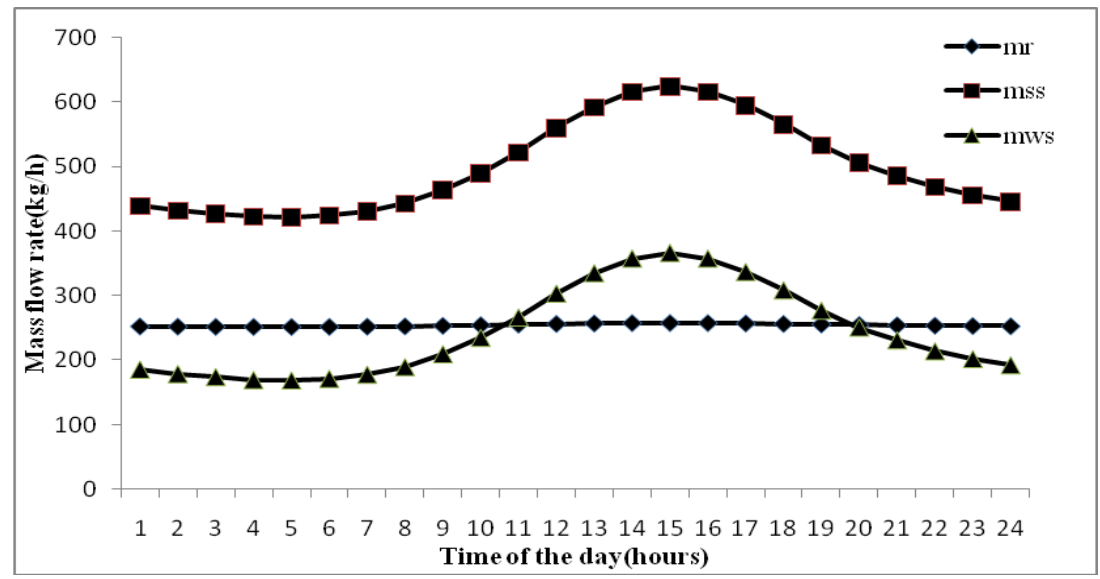

Fig.4 Mass flow rate of refrigerant (mr), strong solution (mss) and weak solution (mws) for the month of January

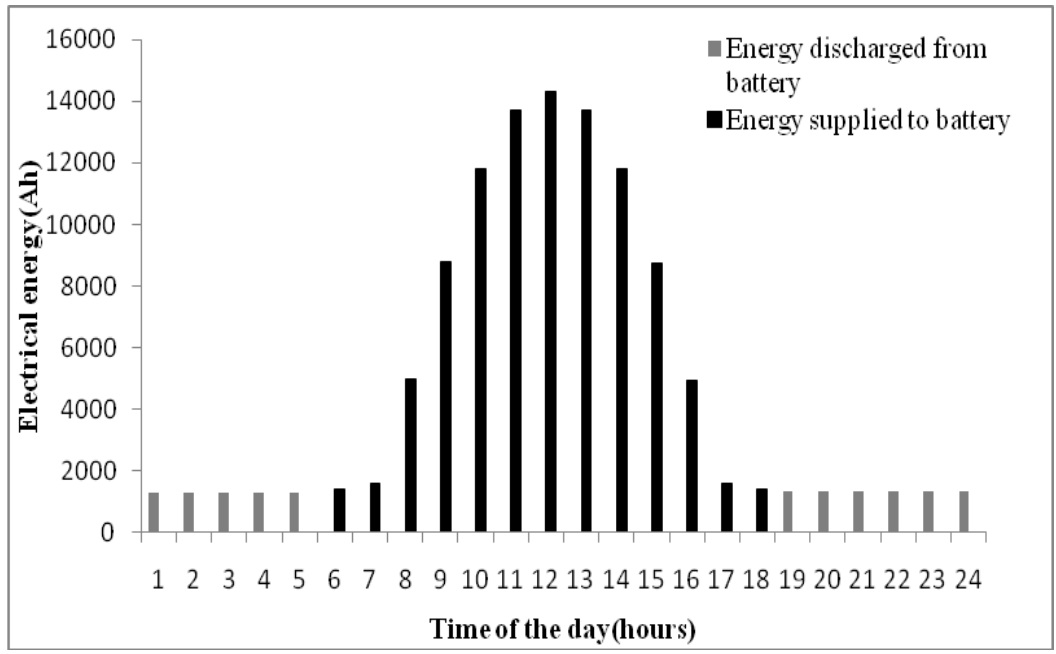

Fig.5. Battery discharge and charging of battery bank for the month of January

\subsection{Analysis for the month of March}

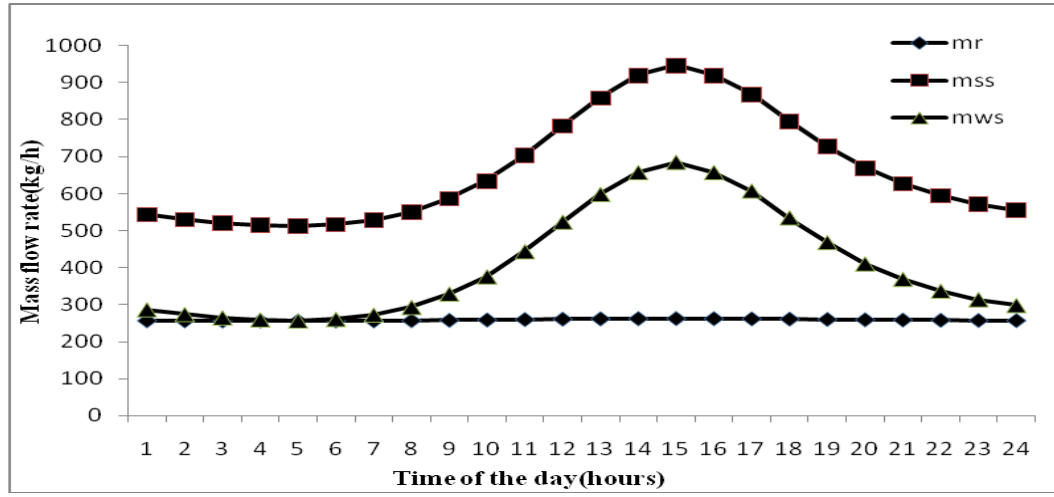

Fig.6 Mass flow rate of refrigerant (mr), strong solution (mss) and weak solution (mws) for the month of March. 


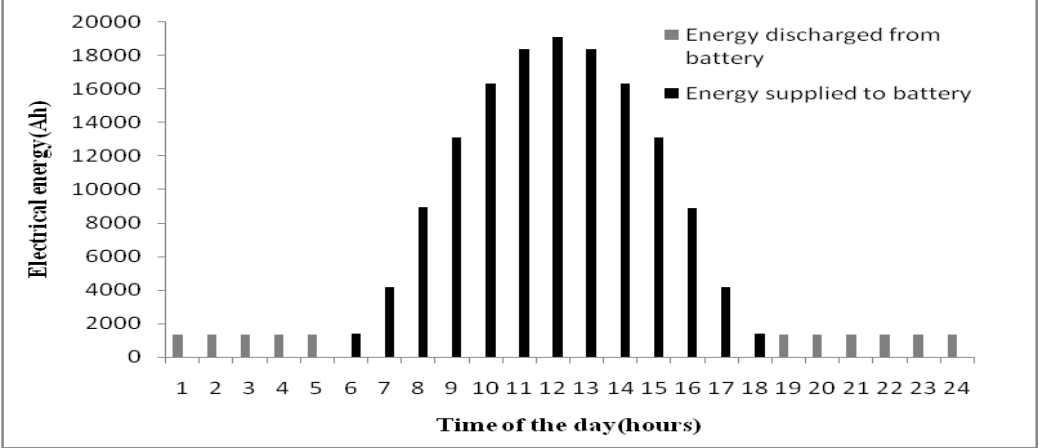

Fig.7. Battery discharge and charging of battery bank for the month of March

4.3 Analysis for the month of May

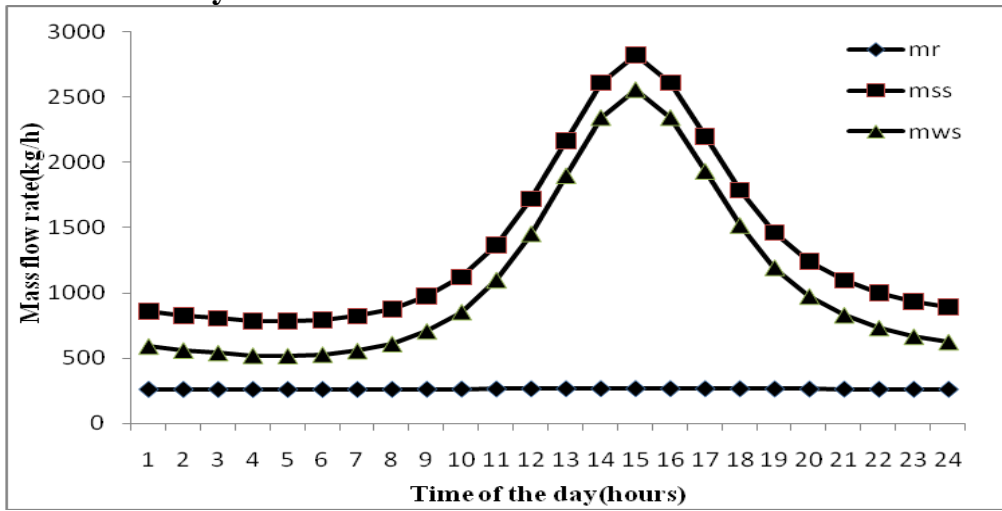

Fig.8 Mass flow rate of refrigerant (mr), strong solution (mss) and weak solution (mws) for the month of May

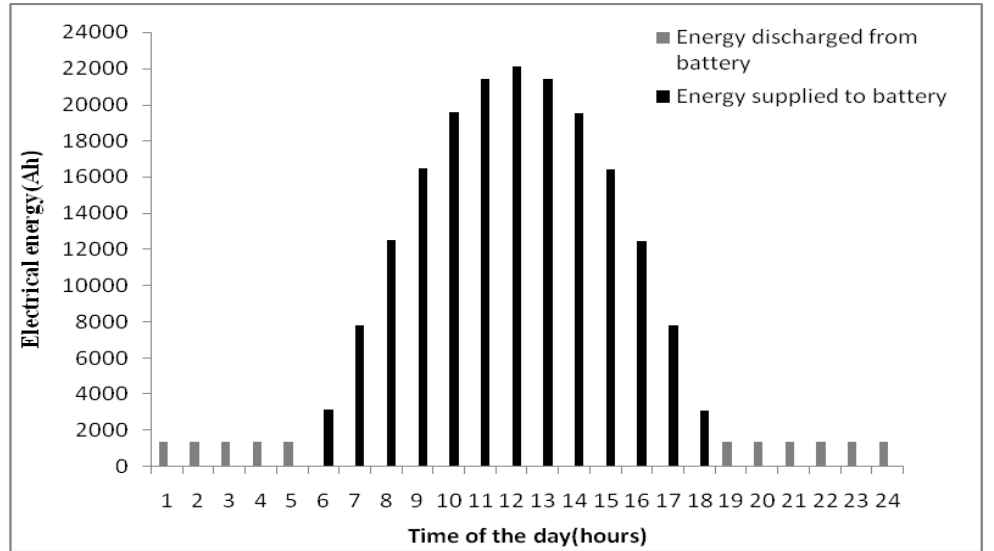

Fig.9. Battery discharge and charging of battery bank for the month of May

\subsection{Analysis for the month of September}

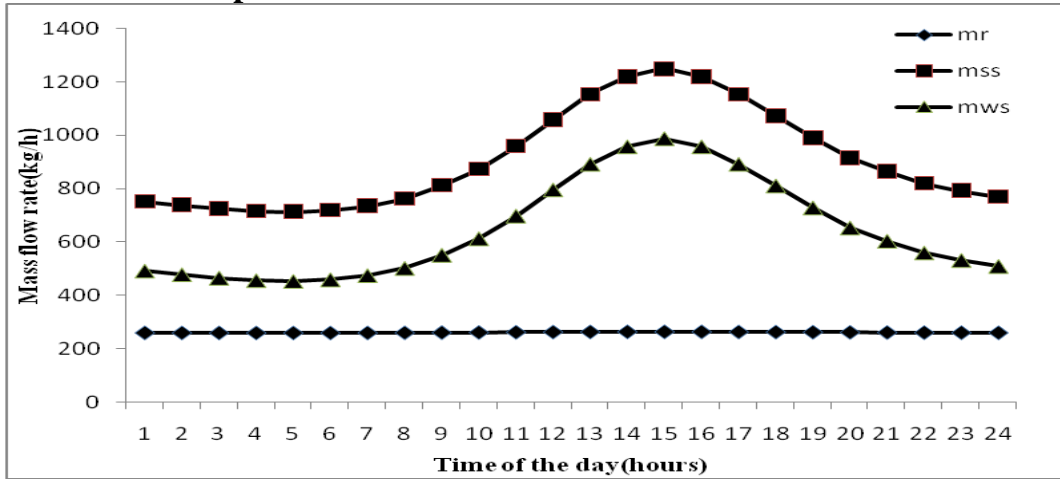

Fig.10 Mass flow rate of refrigerant (mr), strong solution (mss) and weak solution (mws) for the month of September. 


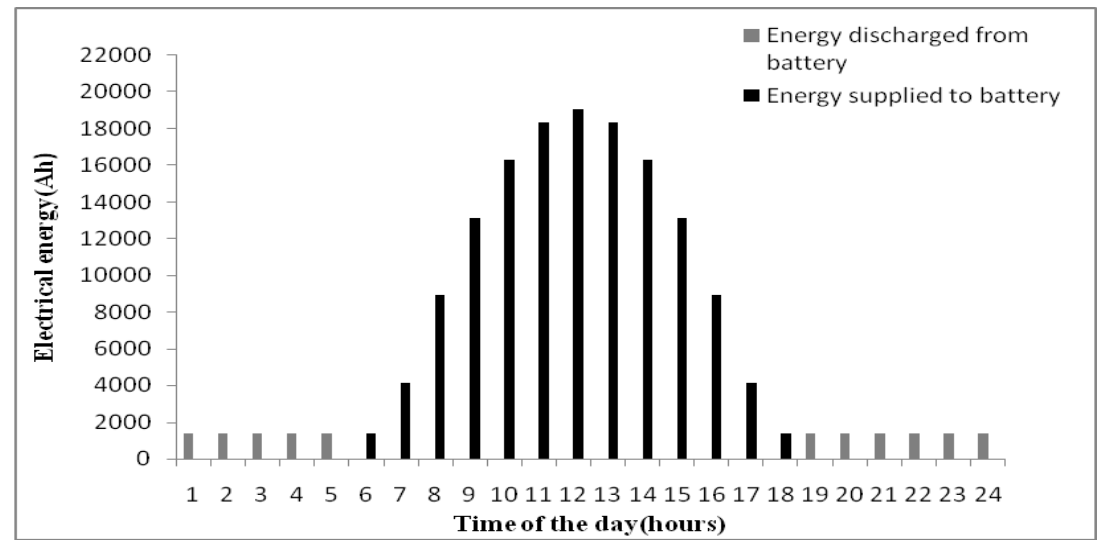

Fig.11 Battery discharge and charging of battery bank for the month of September

In all the four months i.e. January,March,May and September in figures 4,6,8 and 10 refrigerant flow rate is same due to same cooling load i.e. $50 \mathrm{TOR}(1750 \mathrm{~kW})$, strong solution and weak solution flow rate is maximum at 3:00 PM due to maximum temperature and again decreases till 12:00AM. In all the four months i.e. January, March, May and September in figures 5, 7, 9 and 11 sunlight is available from 6:00 AM to 6:00 PM. During 6:00AM to 12:00PM solar radiation increases and again it decreases till 6:00PM, i.e. why battery charging is maximum at 12:00PM and again decreases till 6:00PM.

\subsection{Ice production for different months}

The procedure for ice production calculation and properties of water is taken from ref.[24].

Table 2. Hourly ice production data for different months

\begin{tabular}{|c|c|c|c|c|}
\hline & \multicolumn{5}{|c|}{ Ice produced $(\mathrm{kg} / \mathrm{h})$} \\
\hline Hours & January & March & May & September \\
\hline 1 & 1602.961 & 1477.102 & 1329.64 & 1360.9 \\
\hline 2 & 1615.001 & 1488.792 & 1337.914 & 1365.841 \\
\hline 3 & 1623.713 & 1497.681 & 1343.887 & 1370.816 \\
\hline 4 & 1632.52 & 1503.666 & 1349.914 & 1374.572 \\
\hline 5 & 1634.292 & 1506.677 & 1351.126 & 1375.829 \\
\hline 6 & 1628.986 & 1502.165 & 1347.497 & 1373.318 \\
\hline 7 & 1616.736 & 1490.266 & 1339.104 & 1367.081 \\
\hline 8 & 1596.161 & 1471.326 & 1324.957 & 1357.218 \\
\hline 9 & 1564.632 & 1443.11 & 1304.289 & 1341.491 \\
\hline 10 & 1531.203 & 1413.296 & 1280.976 & 1324.951 \\
\hline 11 & 1496.192 & 1379.612 & 1255.333 & 1306.554 \\
\hline 12 & 1462.746 & 1349.914 & 1232.713 & 1289.758 \\
\hline 13 & 1438.971 & 1328.466 & 1215.784 & 1276.63 \\
\hline 14 & 1423.994 & 1314.542 & 1205.076 & 1269.094 \\
\hline 15 & 1418.625 & 1308.826 & 1201.228 & 1265.892 \\
\hline 16 & 1423.994 & 1314.542 & 1205.076 & 1269.094 \\
\hline 17 & 1437.596 & 1326.125 & 1214.803 & 1276.63 \\
\hline 18 & 1458.494 & 1346.291 & 1229.691 & 1287.552 \\
\hline 19 & 1485.852 & 1369.569 & 1248.046 & 1300.907 \\
\hline 20 & 1512.735 & 1394.957 & 1266.958 & 1315.691 \\
\hline 21 & 1535.891 & 1417.289 & 1284.256 & 1327.294 \\
\hline 22 & 1558.153 & 1437.596 & 1299.783 & 1339.104 \\
\hline 23 & 1576.102 & 1454.266 & 1312.25 & 1347.497 \\
\hline 24 & 1591.098 & 1467.024 & 1321.467 & 1354.775 \\
\hline & & & & \\
\hline
\end{tabular}

It is seen that as time passes from 1:00 hours to 5:00 hours ice production increases due to lesser temperature difference between environment and ice production plant $\left(-10^{\circ} \mathrm{C}\right)$. From 6:00 hours to15:00 hours ice production decreases due to greater temperature difference between environment and ice production plant($10^{\circ} \mathrm{C}$ ). From 16:00 hours to 24:00hours ice production again increases due to lesser temperature difference between environment and ice production plant $\left(-10^{\circ} \mathrm{C}\right)$. 


\subsection{Variation of generator heat load $(\mathrm{Qg})$ at different months}

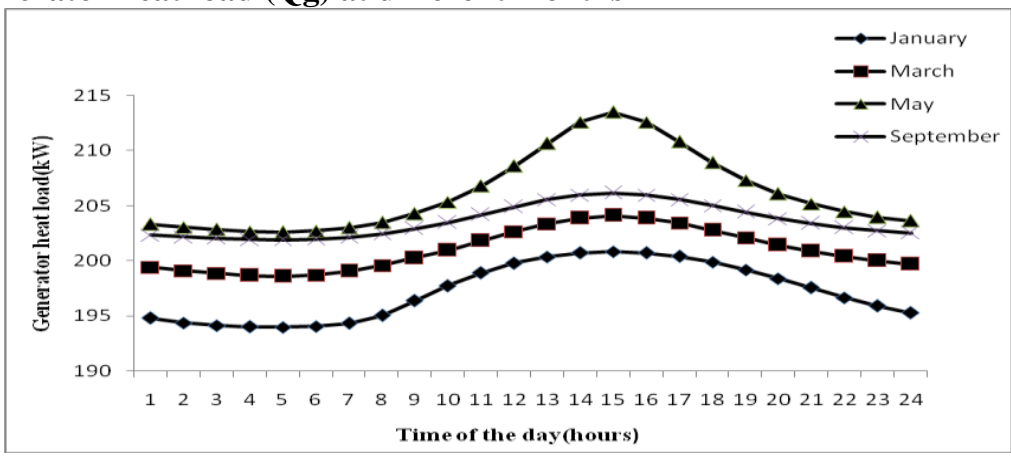

Fig.12 Variation of generator heat load with time at different months

It is seen that generator heat load follows pattern shown in fig.12. As time passes through 1:00 AM to 12:00AM, ambient temperature decreases till 6:00AM and again increases from 7:00AM till 3:00PM and again decreases till 12:00AM. It is found that the generator heat load increases with the time of the day reaching a maximum value at 3:00 PM and again starts decreasing. This is because after sunrise both the intensity of solar radiation and the ambient temperature increase with time reaching their peak values around noon.

\subsection{Energy storage and dissipation by rechargeable battery for different months}

Table 3.Cumulative energy discharge and energy supply to battery bank for different months

\begin{tabular}{|c|c|c|c|c|}
\hline & January & March & May & September \\
\hline Energy to battery(Ah) & 98758.47 & 143641.408 & 183773.429 & 143579.887 \\
\hline Energy from battery(Ah) & 14610.63 & 14914.302 & 15226.41 & 15126.23 \\
\hline
\end{tabular}

\section{Conclusion}

It is found that 5943 modules in parallel( each having two modules in series) of Central Electronics Limited make PM 150 can meet the electrical energy demand of producing ice of ice factory at working load of 50 TOR(tons of refrigeration)VARS throughout the year for New Delhi city. The power back up is provided using battery bank of rated capacity of $59430 \mathrm{Ah}$. It is seen that energy supplied to battery is more than energy discharged from battery for different months representing different seasons of a year. If the working load of ice factory is different from 50 TOR then photovoltaic module requirement and battery bank capacity will be different.

\section{References}

[1]. A.N.N. Chedop, N. Djongyang, and Z. Abdelouahab, Modeling of the performance of a solar electric vapor compression refrigeration system in dry tropical regions, International journal of Science and Research,3(11),2014,1066-1076.

[2]. X.Q. Zhai, M. Qu, Y. Li, and R.Z. Wang, A review for research and new design options of solar absorption cooling systems, Renewable and Sustainable Energy Reviews,15,2011,4416-4423.

[3]. L.A. Chidambaram, A.S. Ramana, G. Kamaraj, and R. Velraj, Review of solar cooling methods and thermal storage options, Renewable and Sustainable Energy Reviews, 15,2011,3220-3228.

[4]. H.Z. Hassan, and A.A. Mohamad, A review on solar cold production through absorption technology. Renewable and Sustainable Energy Reviews, 16, 2012,5331-5348.

[5]. S.M. Hasnain, Review on sustainable thermal energy storage technologies, part II:Cool thermal storage, Energy Conversion and Management,39(11), 1998,1139-1153.

[6]. T.A. Kattakayam, and K. Srinivasan K, Thermal performance characterization of a photovoltaic driven domestic refrigerator, International Journal of Refrigeration, 23, 2000, 190-196.

[7]. M.D. Blas, J. Appelbaum, J.L.Torres, A. Garcia, and de A. Francisco, Characterization of an electric motor directly coupled to a photovoltaic solar array in a refrigeration facility for milk cooling, Biosystems Engineering, 95(3), 2006, 461-471.

[8]. W. Yi, and W. Dong, Modeling and simulation of discharging characteristics of external melt ice on coil storage system, Int. Journal of Smart Home,9(2), 2015,179-192.

[9]. B.L. Gupta, M. Bhatnagar, and J. Mathur, Optimum sizing of PV panel, battery capacity and insulation thickness for a photovoltaic operated domestic refrigerator, Sustainable Energy Technologies and Assessments, 7, 2014, 55-67.

[10]. A. Modi, A. Chaudhuri, B. Vijay, and J. Mathur, Performance analysis of a solar photovoltaic operated domestic refrigerator, Applied Energy, 86(12), 2009,2583-2591.

[11]. A. Cherif, and A. Dhouib, Dynamic modeling and simulation of a photovoltaic refrigeration plant, Renewable Energy, 26(1), 2002, 143-153.

[12]. A. Ganguly, K. Talukdar, and D.N. Basu, Modeling and analysis of a solar photovoltaic assisted absorption refrigeration system, Proceedings of the 4th International Conference on Advances in Energy Research, IIT Bombay,India, 2013, $252-258$.

[13]. A. Saito, Recent advances in research on cold thermal energy storage, Int. Journal of Refrigeration, 25, 2002, 177-189.

[14]. M. Zhang, and Y. Gu, Optimization of ice storage air conditioning system with ASAGA, IEEE workshop on Advanced Research and Technology in Industry Applications(WARTIA), 2014,1042-1046.

[15]. Solar photovoltaic modules pm 150,http:-celindia-co-in.preview1.cp247.net/cal/PM150.pdf;2011[accessed 1.11.2011]. 
[16]. R. Chenni, M. Makhlouf, T. Kerbache, and A. Bouzid, A detailed modeling method for photovoltaic cells, Energy, 32, 2007, 17241730 .

[17]. G.N. Tiwari, Solar energy-Fundamentals,Design, Modeling and Applications, (Narosa Publishing House, New Delhi, 2004).

[18]. Wind speed in Kolkata, West http://www.synergyenviron.com/tools/wind_data.asp?loc=Kolkata\%2CWest+Bengal\%2CIndia,2014 [accessed 12.10.2014].

[19]. Telecommunication Engineering Centre (TEC), New Delhi, Planning and maintenance guidelines for SPV power, http://www.tec.gov.in/guidelines.html,2011 [accessed 23.03.2011].

[20]. S.K. Patra, and P.P. Datta, Some insights into solar photovoltaics-solar home lighting system, NABARD Technical Digest 7 , http://www.nabard.org/,2009 [accessed 26.06.2009].

[21]. F.L. Lansing, Computer modeling of a single stage Lithium Bromide/Water Absorption refrigeration unit, JPL Deep Space Network Progress Report 42-32, DSN Engineering section, 247-257.

[22]. W. Wagner, J.R. Cooper, A. Dittmann, J. Kijima, H.J. Kretzschmar, A. Kruse, R. Mares, K. Oguchi, H. Sato, I. Stocker, O. Sifner, Y. Takaishi, I. Tanishita, J. Trubenbach, and T. Willkommen, The IAPWS Industrial Formulation 1997 for the thermodynamic properties of water and steam, J of Engg. for Gas Turbine and Power ,122, 2000, 150-181.

[23]. J. Patek, and J. Klomfar, A computationally effective formulation of thermodynamic properties of $\mathrm{LiBr}-\mathrm{H} 2 \mathrm{O}$ solutions from 273 to $500 \mathrm{~K}$ over full composition range, Int. J. of Refrigeration, 29, 2006, 566-578.

[24]. http://www.brighthubengineering.com/hvac/78045-how-to-calculate-the-refrigeration-load-for-ice-rinks/,2016(accessed on 2.3.2017) 